\title{
Photoregulation in a Kleptochloroplastidic Dinoflagellate, Dinophysis acuta
}

\author{
Per J. Hansen ${ }^{*}$, Karin Ojamäe2, Terje Berge 1,3, Erik C. L. Trampe ${ }^{1}$, Lasse T. Nielsen ${ }^{3}$, \\ Inga Lips ${ }^{2}$ and Michael Kühl'1,4 \\ ${ }^{1}$ Marine Biological Section, Department of Biology, University of Copenhagen, Helsingør, Denmark, ${ }^{2}$ Marine Systems \\ Institute, Tallinn University of Technology, Tallinn, Estonia, ${ }^{3}$ Centre for Ocean Life, DTU Aqua National Institute for Aquatic \\ Resources, Technical University of Denmark, Charlottenlund, Denmark, ${ }^{4}$ Plant Functional Biology and Climate Change \\ Cluster, University of Technology Sydney, Sydney, NSW, Australia
}

Some phagotrophic organisms can retain chloroplasts of their photosynthetic prey as so-called kleptochloroplasts and maintain their function for shorter or longer periods of time. Here we show for the first time that the dinoflagellate Dinophysis acuta takes control over "third-hand" chloroplasts obtained from its ciliate prey Mesodinium spp. that originally ingested the cryptophyte chloroplasts. With its kleptochloroplasts, D. acuta can synthesize photosynthetic as well as photoprotective pigments under long-term starvation in the light. Variable chlorophyll fluorescence measurements showed that the kleptochloroplasts were fully functional during 1 month of prey starvation, while the chlorophyll a-specific inorganic carbon uptake decreased within days of prey starvation under an irradiance of $100 \mu \mathrm{mol}$ photons $\mathrm{m}^{-2} \mathrm{~s}^{-1}$. While $D$. acuta cells can regulate their pigmentation and function of kleptochloroplasts they apparently lose the ability to maintain high inorganic carbon fixation rates.

Keywords: acquired phototrophy, Dinophysis, kleptochloroplasts, photoregulation, photosynthesis

\section{INTRODUCTION}

Some free-living phagotrophic protists sequester chloroplasts from their algal prey and utilize them for shorter or longer time; a life style that is common among ciliates, dinoflagellates and radiolarians (e.g., Stoecker et al., 2009; Johnson, 2011). In many such species, however, other prey cell organelles are retained as well. Red tide ciliates, Mesodinium spp., ingest certain cryptophyte prey species and sequester not only the chloroplasts (Johnson et al., 2006; Moeller et al., 2011; Hansen et al., 2012), but also a number of other prey cell organelles, such as mitochondria, the prey nucleus, and the nucleomorph (a reduced former nucleus of an earlier endosymbiont found in cryptophytes). These red-pigmented Mesodinium spp. can keep the ingested prey organelles functionally active for several months gaining enough photosynthate for survival in periods of low prey abundance (Johnson and Stoecker, 2005; Hansen and Fenchel, 2006; Johnson et al., 2006, 2007; Smith and Hansen, 2007). In fact, the ingestion of only a single cryptophyte prey cell per day ( $\sim 1 \%$ of daily carbon needs) is sufficient to maintain maximum growth rate (Smith and Hansen, 2007). The red-pigmented Mesodinium spp. can control the division of its ingested prey organelles (Hansen and Fenchel, 2006), but this ability seems to get lost after a few cell divisions in prey-starved cultures probably due to loss of prey nuclei material (Johnson et al., 2007; Moeller et al., 2011). Red-pigmented Mesodinium spp. display photoacclimation, i.e., increases in cellular photosynthetic pigments at low irradiance and a change in photosynthesis vs. irradiance response curves (Johnson et al., 2006; Moeller et al., 2011). 
In other protist species, only prey chloroplasts are sequestered and typically only remain functional in the predator cell for hours up to a few days. However, in some cases such kleptochloroplasts are kept active over several weeks, allowing kleptochloroplastidic predators to survive periods of prey starvation a lot better than purely heterotrophic protists (Stoecker et al., 2009). One conspicuous case is found among the dinoflagellate genus Dinophysis, which are associated with diarrheic shellfish poisoning worldwide. Species within this genus have chloroplasts of cryptophyte origin and the first culture of a Dinophysis spp. was established by feeding it a red-pigmented Mesodinium spp. suggesting that its cryptophyte chloroplasts were supplied from the ciliate prey (Park et al., 2006). This was later confirmed by Kim et al. (2012) and Dinophysis spp. can thus employ "thirdhand" chloroplasts. A total of eight species have now been cultured all relying on red-pigmented Mesodinium spp. as prey (Hansen et al., 2013). Dinophysis spp. use a peduncle to suck out the contents of the ciliate prey. Dinophysis spp. do not ingest cryptophytes directly and thus rely entirely on Mesodinium spp. for the supply of chloroplasts and food. There are no direct evidence suggesting that Dinophysis spp. may feed other protists, detritus, or bacteria (Poulsen et al., 2011; Hansen et al., 2013).

It has recently been shown that Dinophysis acuta and D. caudata, grown together with red Mesodinium spp. under low irradiance have an elevated cellular $\mathrm{Chl} a$ content compared to cells grown at high irradiance (Rial et al., 2013). Dinophysis cells grown under low irradiance contain more and larger kleptochloroplasts as compared to cells grown at high irradiance (Nielsen et al., 2012, 2013). This suggests that Dinophysis spp. may have the capacity to photoregulate, but how is this possible when neither prey nuclei nor nucleomorphs are retained by Dinophysis spp. remains unknown.

The apparent regulation of kleptochloroplasts in Dinophysis spp. could work in three ways, alone or in combination: (i) Behavioral regulation: Dinophysis spp. may increase the number of chloroplasts incorporated via ingestion when grown under low irradiance and may fuse ingested chloroplasts leading to the observed increase in chloroplast size and cellular Chl $a$ content; (ii) Photoregulation: Dinophysis spp. may be able to produce Chl $a$ and other photosynthetic pigments, while the photosynthetic light response curves are unaffected; (iii) Photoacclimation: If Dinophysis spp. perform photoacclimation, an increase in cellular Chl $a$ concentration as well as a change in the photosynthetic light response curve is expected. This would indicate full control over the acquired chloroplasts. In the latter two cases, the genes involved in either of such regulations must have been transferred to the host cell. A few chloroplast housekeeping genes have been found in the genome of Dinophysis acuminata, but it is unlikely that they alone allow for either photoregulation or photoacclimation (Wisecaver and Hackett, 2010).

In the present study, we investigated the photoregulation potential of $D$. acuta cells deprived of prey while being subjected to low irradiance to test whether photoregulation or photoacclimation occurs in sequestered chloroplasts of cryptophyte origin. For this, we employed a suite of different experimental techniques quantifying cell devisions, photosynthetic performance, inorganic carbon $\left(C_{\mathrm{i}}\right)$ uptake, and respiration of $D$. acuta in cultures starved at the initiation of the experiments and incubated at different irradiance levels. We hypothesize that $D$. acuta is only capable of the first of the three options listed above, behavioral regulation, and thus will display no, or limited, control over its kleptochloroplasts during starvation. This would include the lack of ability to synthesize Chl $a$ and limited adaptation of photosynthetic light curve response parameters. Thus, we expect to find an exponential decline in cellular Chl $a$ content as well as declining values of $C_{\mathrm{i}}$ assimilation rate and photosynthetic performance, as cells divide during prey starvation.

\section{MATERIALS AND METHODS}

\section{Organisms and Culture Conditions}

Cultures of the cryptophyte Teleaulax amphioxeia (K-1837; SCCAP) and the ciliate Mesodinium rubrum (MBL-DK2009) were established from water samples from Helsingør Harbor in 2009. Cultures of M. rubrum were fed T. amphioxeia at a predator:prey ratio of 1:10 twice a week. Cultures of $D$. acuta were established in June 2010 from the North Sea (Nielsen et al., 2013). M. rubrum was added as prey organism twice per week at a predator:prey ratio of $\sim 1: 10$ to allow mixotrophic growth. Only M. rubrum cultures that had completely removed their cryptophyte prey were used to feed D. acuta. All three species were grown in $f / 2$ medium (Guillard, 1983) based on autoclaved seawater with a salinity of 32, a dissolved inorganic carbon (DIC) concentration of $2.3 \pm 0.1 \mathrm{mmol} \mathrm{l}^{-1}$ and a pH of $8.0 \pm 0.05$. $\mathrm{pH}$ was monitored directly in the flasks with a SenTix $41^{\circledR} \mathrm{pH}$ electrode (WTW, Germany) connected to a pH meter (WTW, pH 3210, Germany), and calibrated by measurements in $\mathrm{pH} 7$ and pH 10 standard buffers (WTW, Technischer, NIST, buffers). All organisms were grown at $15.0 \pm 1.0^{\circ} \mathrm{C}$ in a temperature regulated room, under a photon irradiance of $100 \mu \mathrm{mol}$ photons $\mathrm{m}^{-2} \mathrm{~s}^{-1}$ (PAR, 400-700 nm), as controlled by a timer to a light:dark cycle of 16:8 h, unless otherwise stated. Culture flasks were placed on a glass table with light coming from below. Light was provided by cool white fluorescent tubes (OSRAM 58W, 840) and photon irradiance was measured (in air) at the level of incubation flasks using a light meter equipped with a spherical quantum sensor (ULM \& US-SQS/L, Walz GmbH, Germany). All cultures were xenic.

\section{Experimental Design Experiment 1}

This experiment was designed to study photoregulation in a recently prey starved culture of $D$. acuta. A culture of $D$. acuta was maintained in $750 \mathrm{ml}$ tissue culture flasks filled with $500 \mathrm{ml}$ culture medium under a photon irradiance of $100 \mu$ mol photons $\mathrm{m}^{-2} \mathrm{~s}^{-1}$ with prey for at least 2 weeks prior to the experiment and was eventually allowed to deplete its ciliate prey (below detection limit which was a few cells $\mathrm{ml}^{-1}$ ). At the initiation of the experiment, subsamples of the culture were split in two and poured into $270 \mathrm{ml}$ tissue culture flasks to capacity at a D. acuta cell density of $200 \mathrm{cells} \mathrm{ml}^{-1}$ (in triplicate). One set 
of flasks were maintained at $100 \mu \mathrm{mol}$ photons $\mathrm{m}^{-2} \mathrm{~s}^{-1}\left(I_{100}\right)$, while the other set of flasks was shifted to a photon irradiance of $15 \mu \mathrm{mol}$ photons $\mathrm{m}^{-2} \mathrm{~s}^{-1}\left(I_{15}\right)$. Subsamples were withdrawn on day $3,6,9,13,16$, and $29\left(I_{100}\right)$, and day $4,7,10,14,17$, and $30\left(I_{15}\right)$ for measurements of cell concentration, ${ }^{14} \mathrm{C}$ fixation, algal pigment concentration using both fluorometry and HPLC techniques, photosynthetic capacity using variable chlorophyll fluorimetry, and $\mathrm{O}_{2}$ optode-based respiration measurements (see descriptions of these techniques below).

$\mathrm{pH}$ was checked on each sampling occasion to avoid physiological effects of elevated $\mathrm{pH}$ in laboratory cultures (Hansen, 2002). Any cryptophytes left in the incubation flasks at the start of the experiment grew to concentrations where they could affect $\mathrm{pH}$, especially at $I_{100}$. As the Dinophysis culture increased in cell concentration they also affected the $\mathrm{pH}$ of the culture medium. Therefore, we removed most of the culture medium once each week during the experiment, using gentle inverse filtration, and applied fresh $\mathrm{f} / 2$ culture medium to ensure optimal growth conditions (i.e., nutrients, $\mathrm{pH}$, etc.). A plastic tube with plankton gauze (mesh size $20 \mu \mathrm{m}$ ) attached to the tip was lowered directly into the experimental flasks and 90\% "old" growth medium was removed gently using a pipette and replaced with fresh growth medium. This was repeated three times each time.

\section{Experiment 2}

This experiment was carried out to measure Chl $a$, and physiological rates in well fed cultures of $D$. acuta at an irradiance of $100 \mu \mathrm{mol}$ photons $\mathrm{m}^{-2} \mathrm{~s}^{-1}$. Cultures were maintained in $750 \mathrm{ml}$ tissue culture flasks filled with $500 \mathrm{ml}$ culture medium prior to the experiment. At the initiation of the experiment, $270 \mathrm{ml}$ tissue culture flasks were filled to capacity with an initial concentration of $400 \mathrm{D}$. acuta cells $\mathrm{ml}^{-1}$ and $1000 \mathrm{M}$. rubrum cells $\mathrm{ml}^{-1}$ (in triplicate). Samples were withdrawn three times over 6 days for measurements of cell concentration, ${ }^{14} \mathrm{C}$ fixation, photosynthetic capacity using variable chlorophyll fluorimetry, and $\mathrm{O}_{2}$ optode-based respiration measurements (see descriptions of these techniques below). Fresh growth medium was added at each sampling to replace the water volume removed. Dinophysis cells were picked individually using a drawn Pasteur glass pipette and transferred to clean growth medium twice to remove all M. rubrum cells before measurements.

\section{Cell Enumeration}

Cells were fixed in Lugol's solution ( $1 \%$ final conc.) and were enumerated using a Sedgewick Rafter cell and an inverted microscope (Olympus ${ }^{\circledR}, \mathrm{CK}-40$ ). A minimum of 200 Dinophysis cells were counted each time and all samples were checked for possible lefteover of ciliate prey cells.

\section{Photosynthetic Pigments Fluorimetric Measurements of Algal Pigments}

Cellular chlorophyll concentration was measured by extracting chlorophyll of single cells according to Skovgaard et al. (2000). One $\mathrm{ml}$ of $96 \%$ ethanol was added to the borosilicate measuring vials. A total of 80 individual Dinophysis cells were pipetted directly into the ethanol and placed in the dark. This process took place in a temperature-regulated room kept at experimental temperature. The chlorophyll a concentration ( $\mu \mathrm{g}$ Chl $a \mathrm{l}^{-1}$ ) was measured in the extract after 20 min using a bench-top fluorometer (Trilogy, Turner designs, USA) equipped with the manufacture's module for $\mathrm{Chl} a$ determination. The fluorometer was calibrated against a pure Chl $a$ standard (2.13 mg Chl $\left.a \mathrm{l}^{-1}\right)$ of cyanobacterial origin (DHI, Hørsholm, Denmark).

Additionally, we measured the in vivo chlorophyll, and phycoerythrin fluorescence using the appropriate filter set modules for the fluorimeter. For this, 80 individual Dinophysis cells were isolated and transferred into plastic measuring cuvettes containing $1 \mathrm{ml}$ of fresh medium. The cells were kept in suspension by carefully blowing air with a pipette immediately before the measurements. Due to high variation between single measurements, the in vivo fluorescence was measured every second and averaged over a period of $10 \mathrm{~s}$.

\section{Photopigment Analysis}

We analyzed the pigment composition of $D$. acuta with high-pressure liquid chromatography (HPLC) using a slightly modified method from Frigaard et al. (1996) measuring the major light harvesting pigment $\mathrm{Chl} a$, the photoprotective pigment alloxanthin, and the ratio between the two in D. acuta throughout the starvation experiments. For pigment conservation prior to HPLC analysis, 200 D. acuta cells were picked with a micropipette and transferred twice into fresh growth medium, before they were spun down at $10 \mathrm{~g}$ for $5 \mathrm{~min}$. The supernatant was removed, and the pellet was frozen at $-80^{\circ} \mathrm{C}$. Before HPLC analysis, each pellet containing $200 \mathrm{D}$. acuta cells was resuspended for pigment extraction in $125 \mu \mathrm{l}$ of an acetone-methanol (7:2, vol/vol) mixture and sonicated using an ultrasonicator (Misonix 4000, Qsonica LLC., Newtown, CT, USA) under dim light for $20 \mathrm{~s}$. The sonicated cells were extracted in darkness on ice for $2 \mathrm{~min}$. The extracts were briefly centrifuged to pellet cell debris, and the supernatants were mixed with $15 \mu \mathrm{L}$ ammoniumacetate $(1 \mathrm{M})$ in $0.3 \mathrm{ml} \mathrm{HPLC}$ vials. A $100 \mu \mathrm{L}$ sample of the mixture was then immediately injected into the HPLC.

Pigment extracts were separated and analyzed by a diode array detector connected to the HPLC system (HPLC-DAD \& Agilent 1260 Infinity, Agilent Technologies, Santa Clara, CA, USA) fitted with a Nova-pak C18 column (dimensions: $3.9 \times 300 \mathrm{~mm}$ ), detecting specific absorption wavelengths of compounds. The extracts were run at a column temperature of $30^{\circ} \mathrm{C}$ for $69 \mathrm{~min}$. Injected extracts moved with a flow-rate of $1.0 \mathrm{ml} \mathrm{min}{ }^{-1}$ in solvent A (methanol:acetonitrile:water, 42:33:25, $\mathrm{vol} / \mathrm{vol} / \mathrm{vol}$ ), and solvent B (methanol:acetonitrile:ethyl acetate, $50: 20: 30, \mathrm{vol} / \mathrm{vol} / \mathrm{vol})$. In the separation process, the mobile phase changed linearly from $30 \%$ solvent $\mathrm{B}$ at the time of injection to $100 \%$ at $52 \mathrm{~min}$, staying at $100 \%$ for $15 \mathrm{~min}$ and then falling back to $30 \%$ within $2 \mathrm{~min}$. Chl $a$ and alloxanthin were identified manually from HPLC chromatograms, and pigment ratios were calculated from the derived integrated peak areas using the manufacturers software (OpenLAB CDS ChemStation Edition, Agilent Technologies, Santa Clara, CA, USA).

\section{Variable Chlorophyll Fluorescence Analysis}

We assessed the photosynthetic capacity of $D$. acuta, mainly by means of evaluating the dark adapted maximum PSII quantum 
yield, $F_{\mathrm{v}} / F_{\mathrm{m}}$ as measured by the pulse saturation method with pulse-amplitude modulated (PAM) fluorimeters (Schreiber et al., 1994). Individual cells were imaged with a variable chlorophyll fluorescence imaging system (RGB Microscopy PAM, Walz GmbH, Germany; Trampe et al., 2011), while bulk culture samples were investigated in a cuvette-based chlorophyll fluorimeter (MULTI-COLOR-PAM; Walz GmbH, Germany). Detailed descriptions of the two types of PAM measurements, and definitions of the parameters used, are provided in the Supplementary Material, Section Material and Methods.

\section{Sample preparation - Imaging PAM}

$1.5 \mathrm{ml}$ subsamples of $D$. acuta culture were transferred to $1.5 \mathrm{ml}$ tubes and centrifuged at $43 \mathrm{~g}$ for $2 \mathrm{~min}$. The $1.4 \mathrm{ml}$ supernatant was removed, and the pellet was resuspended in the remaining $0.1 \mathrm{ml}$ yielding a concentrated sample facilitating a low search time for cells of interest at high magnification under the microscope. Control experiments showed no significant effect on cell structure or photosynthetic capacity by the treatment (data not shown). A droplet $(16.5 \mu \mathrm{L})$ of concentrated sample was transferred to a special treated microscope slide displaying a permanently positive charge (Superfrost Ultra Plus, Thermo Scientific, Gerhard Menzel GmbH, Braunschweig, Germany) resulting in good cell adhesion by electrostatic attraction, limiting motion of cells during imaging. Variable chlorophyll fluorescence imaging measurements rely on recording of consecutive images when calculating photosynthetic parameters, and it is thus crucial that there is no cell movement during the saturation pulse. The sample was sealed with a cover glass using petroleum jelly (Vaseline $^{\mathrm{TM}}$ ) at the periphery to avoid evaporation, and the slide was placed at $12^{\circ} \mathrm{C}$ in a thermostated slide holder (see details in Trampe et al., 2011).

\section{Sample prepation - MULTI-COLOR PAM}

For each sample, 1000 (Experiment 1) or 300 (Experiment 2) cells were isolated with a drawn out Pasteur pipette and transferred several times through sterile-filtered seawater before final transfer into quartz cuvettes and the volume was adjusted to $1 \mathrm{ml}$ using 30 psu sterile-filtered f/2 medium. Samples were stirred with a magnetic stirrer during measurements.

\section{Inorganic Carbon Uptake and Respiration \\ ${ }^{14} \mathrm{C}$ Incorporation}

Subsamples (1-2 ml) were removed from each culture flask for photosynthesis measurements. A total of $80 \mathrm{D}$. acuta cells were picked from the subsamples and washed in f/2 medium by micromanipulation using a stereoscope to remove all prey. A total of $40 \mathrm{D}$. acuta cells were transferred to each of two $20 \mathrm{ml}$ glass scintillation vials containing $2 \mathrm{ml} \mathrm{f} / 2$ medium, and $20 \mu \mathrm{l}$ of a $\mathrm{NaH}^{14} \mathrm{CO}_{3}$ stock solution (specific activity $=100 \mu \mathrm{Ci}$ $\mathrm{ml}^{-1}$; Carbon-14 Centralen, Denmark) was added. One vial was incubated for $\sim 3 \mathrm{~h}$ under the treatment irradiance, while the other was kept in complete darkness (by wrapping in several layers of aluminum foil). After incubation, a $100 \mu \mathrm{L}$ sub-sample was transferred to a new vial containing $200 \mu \mathrm{l}$ phenylethylamine for determination of specific activity (see Skovgaard et al., 2000 for a detailed method description). The remaining $1.9 \mathrm{ml}$ were acidified with $2 \mathrm{ml} 10 \%$ glacial acetic acid in methanol, and evaporated overnight at $60^{\circ} \mathrm{C}$ to remove all inorganic carbon. The residue was then re-dissolved in $2 \mathrm{ml}$ Milli-Q water. All vials were treated with $10 \mathrm{ml}$ Packard Insta-Gel Plus scintillation cocktail, and disintegrations per minute were measured using a Packard 1500 Tri-Carb liquid scintillation analyzer with automatic quench correction. The photosynthetic activity (PA, pg $\mathrm{C}$ cell ${ }^{-1} \mathrm{~h}^{-1}$ ) per cell was calculated as follows:

$$
\mathrm{PA}=\frac{\mathrm{DPM} \times[\mathrm{DIC}]}{{ }^{14} \mathrm{C} \times h \times N}
$$

where DPM is disintegrations $\min ^{-1}$ (in $1.9 \mathrm{ml}$ ) in the light corrected for dark values, DIC is the concentration of DIC (pg C $\mathrm{ml}^{-1}$ ), ${ }^{14} \mathrm{C}$ is the specific activity (disintegrations $\mathrm{min}^{-1} \mathrm{ml}^{-1}$ ), $h$ is the incubation time, and $N$ is the number of cells in the vial $(1.9 \mathrm{ml})$. DIC concentrations were measured on $1 \mathrm{ml}$ subsamples using an infrared gas analyzer (ADC 225 Mk3 Gas analyzer, Analytic Development Co. Ltd., Hoddesdon, England) as described in detail elsewhere (Nielsen et al., 2007). Glass vials with screw caps were used for DIC samples allowing no headspace, and the samples were analyzed within a few hours.

\section{Respiration Measurements}

Respiration rates of $D$. acuta were measured in $1.8 \mathrm{ml}$ glass vials $(n=4)$ equipped with calibrated optical $\mathrm{O}_{2}$ sensor spots with optical isolation (Pyroscience $\mathrm{GmbH}$, Germany). The $\mathrm{O}_{2}$ dependent luminescence of each sensor spot was monitored contactless across the vial wall using an optical fiber cable fixed at one end to the glass vial using a solid plexi-glass adaptor and connected at the other end to a fiber-optic $\mathrm{O}_{2}$ meter (FireSting, PyroScience, Germany). The sensor spot readout was calibrated from readings in anoxic and fully aerated medium. A total of 400 Dinophysis cells were isolated by micropipetting and washed 3 times in sterile filtered (pore size $0.22 \mu \mathrm{m}$ ) $\mathrm{f} / 2$ culture medium prior to addition to each of the 4 glass vials containing $1 \mathrm{ml}$ sterile $\mathrm{f} / 2$ medium. A glass bead was added to each of the vials that were filled to capacity with sterile filtered medium and carefully sealed avoiding any air bubbles inside the closed vials. The vials were mounted on a modified whirley mixer run at low speed to homogenize internal $\mathrm{O}_{2}$ gradients in the sample (Trampe et al., 2015). The measurements were done in darkness in a temperature regulated room $\left(15^{\circ} \mathrm{C}\right)$, and $\mathrm{O}_{2}$ was measured with the built-in temperature correction of the $\mathrm{O}_{2}$ meter. The $\mathrm{O}_{2}$ concentration in the glass vials was measured for $1-3 \mathrm{~h}$, and the linear decrease in $\mathrm{O}_{2}$-concentration $\left(\mu \mathrm{mol} \mathrm{l} \mathrm{l}^{-1} \mathrm{~s}^{-1}\right.$ ) was converted into cellular respiration rate ( $\mathrm{pg} \mathrm{C} \mathrm{cell}^{-1} \mathrm{day}^{-1}$ ) by assuming a respiratory quotient of 1 .

\section{RESULTS}

\section{Changes in Photosynthetic Pigments in D. acuta Starved of Prey}

No ciliate prey cells were observed during enumeration of Dinophysis cells for the entire duration the prey starvation experiment. D. acuta cultures subjected to prey starvation at high photon irradiance $\left(I_{100}=100 \mu \mathrm{mol}\right.$ photons $\left.\mathrm{m}^{-2} \mathrm{~s}^{-1}\right)$ increased 
from 200 to 1400 cells $\mathrm{ml}^{-1}$ during 1 month of incubation, equivalent to an average growth of 2.8 cell divisions in total (Experiment 1, Figure 1A). The subculture that was exposed to low photon irradiance $\left(I_{15}=15 \mu \mathrm{mol}\right.$ photons $\left.\mathrm{m}^{-2} \mathrm{~s}^{-1}\right)$ increased in cell concentration from 200 to 1000 cells $\mathrm{ml}^{-1}$ and thus had $<2.3$ cell divisions during the 1 month of incubation (Figure 1A). The cellular $\mathrm{Chl}$ a concentration in D. acuta incubated at $I_{100}$ decreased exponentially from the initial $\sim 53-$ $16 \mathrm{pg}$ Chl $a$ cell $^{-1}$ (Figure 1B), leading to an overall increase in Chl $a$ concentration from 11 to a maximum of $26 \mathrm{ng}$ Chl $a$ $\mathrm{ml}^{-1}$ at Day 16 (Figure 1C). Cells incubated at $I_{15}$, however, maintained their cellular Chl a concentration during the 1 month long incubation, even though cells divided 2.3 times. This led to an increase in the amount of $\mathrm{Chl} a$ in these incubations from 11 to $46 \mathrm{ng} \mathrm{Chl} a \mathrm{ml}^{-1}$ at Day 30, indicating a higher net production of Chl $a$ production in prey-starved Dinophysis cells grown at $I_{15}$, compared to those at $I_{100}$ (Figure 1C). For comparison, well fed cultures of D. acuta grown at $I_{100}$ had a cellular Chl $a$ concentration of $\sim 40 \mathrm{pg} \mathrm{Chl} a$ cell $^{-1}$ (Experiment 2).

Cultures exposed to $I_{100}$ exhibited a slight increase in the alloxanthin:Chl $a$ ratio from 0.86 to $\sim 1.2$ over the first 10 days. Hereafter, the ratio remained constant indicating that Chl $a$ was initially lost at a faster rate than alloxanthin (Figure 2A). With cultures exposed to $I_{15}$, a significant decrease in the alloxanthin:Chl $a$ ratio from 0.86 to 0.7 was observed over the first 2 weeks indicating dilution due to growth, which was followed by an increase of the alloxanthin:Chl $a$ ratio reaching $\sim 1$ at the end of the experiment. In vivo measurements of Chl $a$ and phycoerythrin showed that the changes in phycoerythrin content under the two experimental irradiance regimes matched those found in Chl $a$ (Figure 2B).

\section{Single-Cell Variable Chlorophyll Fluorescence Imaging}

In well fed cultures of $D$. acuta, incubated at an irridiance of $100 \mu \mathrm{mol}$ photons $\mathrm{m}^{-2} \mathrm{~s}^{-1}$, microscopy revealed a broad distribution of cellular Chl $a$ with hotspots clearly defining 4-5 chloroplast centers with high fluorescence. Maximum PSII quantum yields $\left(F_{\mathrm{V}} / F_{\mathrm{m}}\right)$ of $\sim 0.5$ in these centers indicated a healthy and functioning photosynthetic apparatus (Figure 3A). During the starvation experiment at $I_{100}$, we found a continuously declining $\mathrm{Chl} a$ coverage in the cells with incubation time (Figures 3B-D). After a slight increase in $F_{\mathrm{v}} / F_{\mathrm{m}}$ over the first 2 days, $F_{\mathrm{V}} / F_{\mathrm{m}}$ decreased with the declining chlorophyll coverage (Figure 3B; Supplementary Figure S1). At $I_{15}$ we observed a rapid increase in $F_{\mathrm{v}} / F_{\mathrm{m}}$ to $\sim 0.6$ over the first 3 days, which remained high even after 10 days, while the $\mathrm{Chl} a$ coverage had decreased a bit (Figures 3E,F; Supplementary Figure S1). After 30 days, we still observed an even coverage, almost similar to the well-fed cells, with similar condensation in four chloroplast centers, and with a sustained high level of $F_{\mathrm{V}} / F_{\mathrm{m}}$ (Figure 3G).

\section{Bulk Measurements of Photochemical and Non-photochemical Quenching}

Measurements on bulk cell samples yielded more insight into the photochemical, and non-photochemical quenching processes

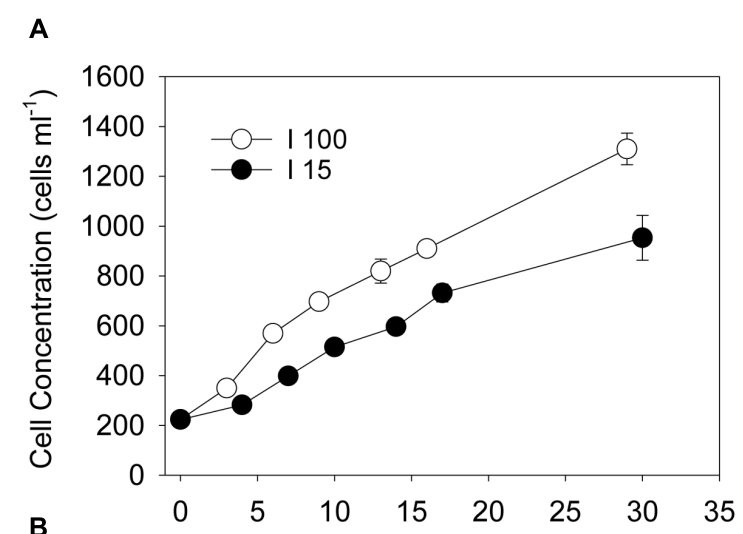

B

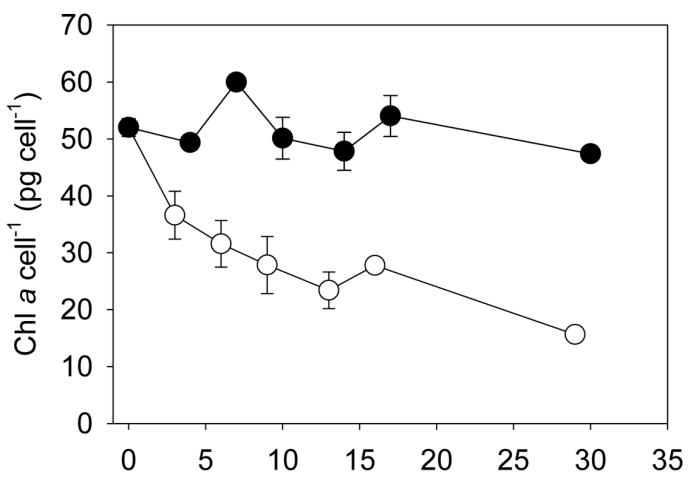

C

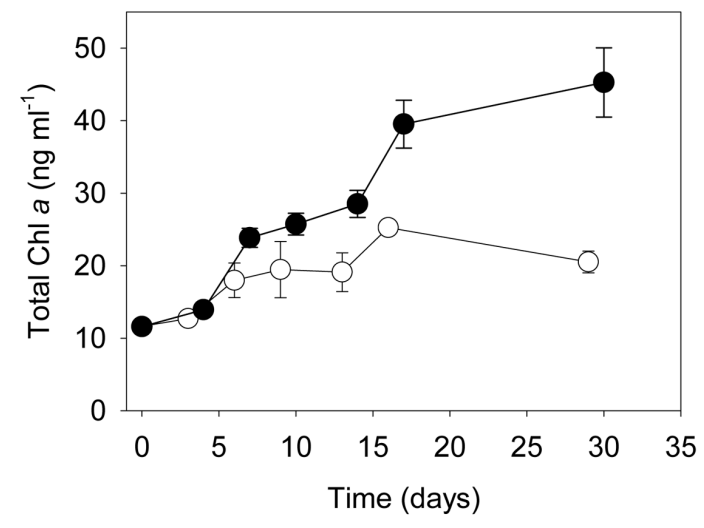

FIGURE 1 | Developments in Dinophysis acuta cell concentrations, cellular $\mathrm{Chl}$ a content and total $\mathrm{Chl}$ a concentrations when subjected to prey starvation at the start of the experiment and incubated for 1 month under an irradiance of (o) $100 \mu \mathrm{mol}$ photons $\mathrm{m}^{-2} \mathrm{~s}^{-1}\left(I_{100}\right)$ and (๑) $15 \mu \mathrm{mol}$ photons $\mathrm{m}^{-2} \mathrm{~s}^{-1}\left(I_{15}\right)$, respectively. (A) cell

concentration (cells ml-1), (B) cellular Chl a concentration (pg Chl a cell ${ }^{-1}$ ), (C) total Chl a concentration (ng Chl a $\mathrm{ml}^{-1}$ ). Data points represent treatment means and error bars indicate standard errors $(n=3)$.

in starved $D$. acuta cultures. The maximum PSII quantum yield $\left(F_{\mathrm{v}} / F_{\mathrm{m}}\right)$ was on average higher for cells at $I_{15}(0.74 \pm 0.04$; average \pm SE, $n=18)$ than $I_{100}(0.65 \pm 0.05, n=21$; Figure 4A). In both treatments, $F_{\mathrm{v}} / F_{\mathrm{m}}$ showed an initial increase during the 1 week, but only cells at $I_{15}$ were able to maintain a high $F_{\mathrm{v}} / F_{\mathrm{m}}$ of $\sim 0.76$, indicating better photosynthetic capacity than cells at $I_{100}$. The change in $F_{\mathrm{v}} / F_{\mathrm{m}}$ resulted primarily from the change in 


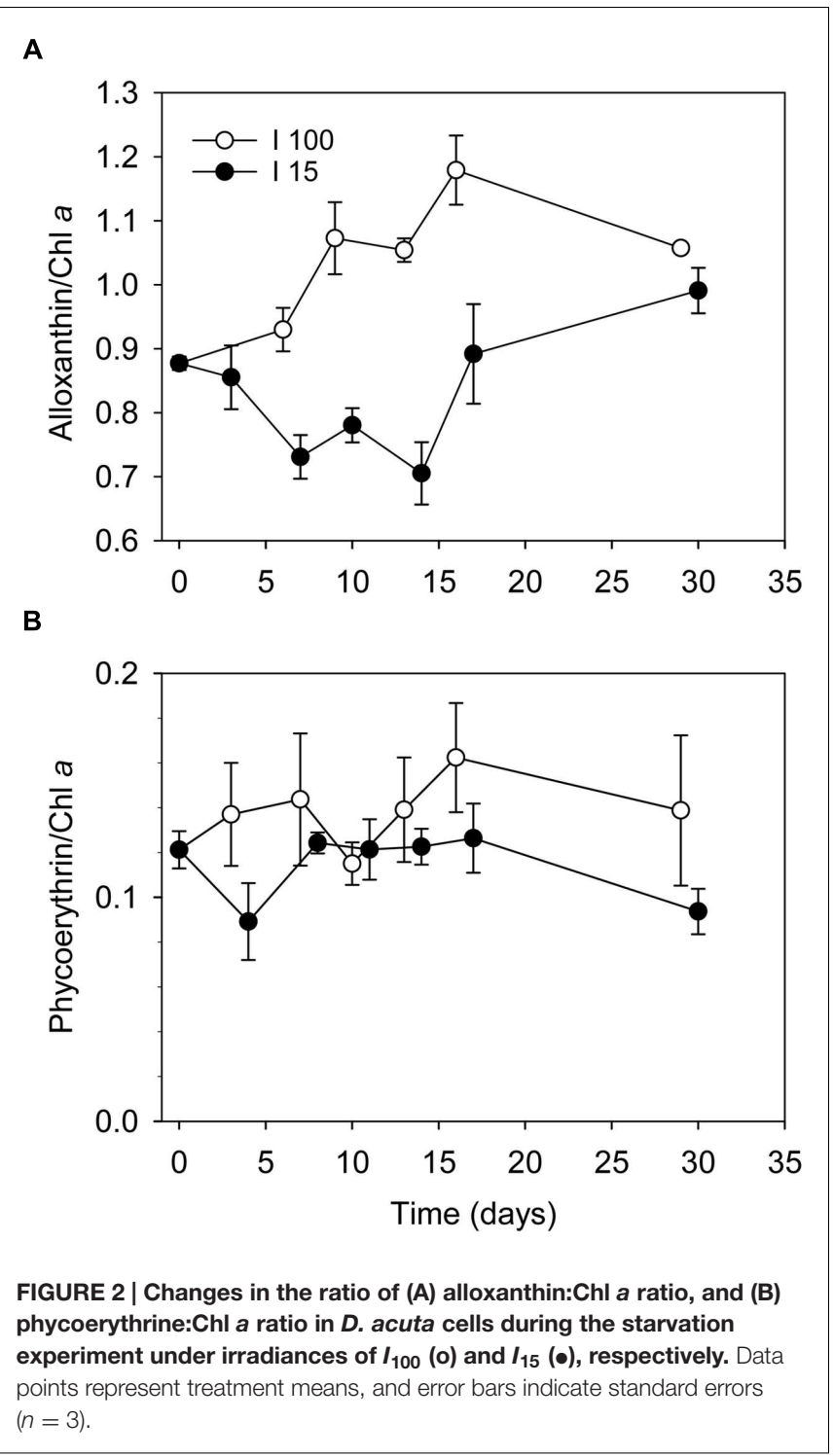

the fraction of "open" PSII reaction centers, $\mathrm{qP}$ (Supplementary Figure S2A). An increase in $\mathrm{qP}$ to $0.94 \pm 0.02(n=15)$ at $I_{15}$ indicates a decrease in the proportion of "closed" PSII centers due to lower excitation pressure, than compared to cells at $I_{100}$, which had a lower $\mathrm{qP}$ of $0.67 \pm 0.02(n=21)$ throughout the starvation experiment.

Absorbed light energy partitioning profiles for D. acuta (Supplement Figures S2A,B) show a photoregulative change in response to changes in photon irradiance. The use of excitation energy for photosynthesis $\left(\phi_{I I}\right)$ in cultures kept at $I_{100}$ was lowered with respect to $F_{\mathrm{v}} / F_{\mathrm{m}}$ by partial closure of PSII centers (Supplementary Figure S2A), and non-photochemical energy losses ( $\phi_{\mathrm{NPQ}}$ and $\phi_{\mathrm{NO}}$ ) induced by illumination. Only $38 \%$ of the absorbed light energy was used for photosynthetic reactions (Supplementary Figure S2B), whereas cells kept at $I_{15}$ used $70 \%$ of the absorbed light for photosynthesis (Supplementary Figure S2C).
The maximum relative electron transport rate $\left(\mathrm{rETR}_{\max }\right)$, and the initial slope of the light response curves ( $\alpha$ rETR) showed no changes between the treatments (Figures $4 \mathrm{~B}, \mathrm{C}$ ). For cultures incubated at $I_{100}$, the average $\mathrm{rETR}_{\max }$ and $\alpha$ rETR values were $76.3 \pm 8.14$ and $0.25 \pm 0.01(n=21)$, respectively. Cultures at $I_{15}$ showed average $\mathrm{rETR}_{\max }$ and $\alpha \mathrm{rETR}$ values of $88.2 \pm 2.58$ and $0.31 \pm 0.02(n=18)$, respectively, (Figures 4B,C).

\section{Inorganic Carbon Uptake and Respiration before and during Starvation}

Inorganic carbon uptake was $138 \pm 6 \mathrm{pg} \mathrm{C}$ cell $^{-1} \mathrm{~h}^{-1}$ (average $\pm \mathrm{SE}$ ) in well fed cultures of $D$. acuta at $I_{100}$, equivalent to $2.21 \pm 0.94 \mathrm{ng} \mathrm{C}$ cell $^{-1}$ day $^{-1}$ (light:dark cycle of 16:8 h), leading to a Chl $a$ specific rate of $3.5 \pm 0.5 \mathrm{pg} \mathrm{C} \mathrm{pg} \mathrm{Chl} a^{-1}$. The inorganic carbon uptake of $D$. acuta cells subjected to starvation at $I_{100}$ decreased exponentially from $177 \pm 14$ to $23.7 \pm 4.2 \mathrm{pg}$ $\mathrm{C}$ cell $^{-1} \mathrm{~h}^{-1}$ at Day 16 (equivalent to $2.83 \pm 0.23$ and $0.38 \mathrm{ng} \mathrm{C}$ cell $^{-1}$ day $^{-1}$, respectively, Figure 5A), i.e., a 6.1-fold decrease in photosynthetic carbon fixation. This translated into a significant decline in the Chl $a$-specific carbon uptake from the initial 3.4 to $1.0 \mathrm{pg} \mathrm{C} \mathrm{pg} \mathrm{Chl} a^{-1} \mathrm{~h}^{-1}$ at Day 16 (one-way ANOVA, $P<0.05$; Figure 5B). The following 2 weeks, the inorganic carbon uptake rate dropped further to $16.8 \pm 1.1 \mathrm{pg} \mathrm{C}$ cell ${ }^{-1} \mathrm{~h}^{-1}$ $\left(=0.27 \pm 0.02 \mathrm{ng} \mathrm{C}\right.$ cell $\left.^{-1} \mathrm{day}^{-1}\right)$, but the Chl $a$-specific carbon uptake stayed constant (1.07 pg C pg Chl $a^{-1} \mathrm{~h}^{-1}$ ).

Under low irradiance $\left(I_{15}\right)$, inorganic carbon uptake remained constant for the first 17 days at $33.1 \pm 2.8 \mathrm{pg} \mathrm{C}$ cell $^{-1} \mathrm{~h}^{-1}$ $\left(=0.53 \pm 0.03 \mathrm{ng} \mathrm{C}\right.$ cell $\left.^{-1} \mathrm{day}^{-1}\right)$, and dropped only marginally to $20.7 \pm 1.9 \mathrm{pg} \mathrm{C}$ cell $^{-1} \mathrm{~h}^{-1}\left(=0.33 \pm 0.03 \mathrm{ng} \mathrm{C}\right.$ cell $^{-1}$ day $\left.^{-1}\right)$ after 1 month of incubation. Thus, the Chl $a$-specific inorganic carbon uptake rates of the starved low irradiance $D$. acuta stayed constant at $\sim 0.6-0.7 \mathrm{pg} \mathrm{C} \mu \mathrm{g} \mathrm{Chl} a^{-1} \mathrm{~h}^{-1}$ during the entire experiment.

Well-fed cells of $D$. acuta had a respiration rate of $86.5 \pm 0.16 \mathrm{pg} \mathrm{C}$ cell $^{-1} \mathrm{~h}^{-1}$ at $I_{100}$, equivalent to $2.08 \pm 0.38 \mathrm{ng} \mathrm{C}$ cell $^{-1}$ day $^{-1}$ (average $\pm \mathrm{SE}, n=9$ ). No difference in respiration rate was observed as a function of prey starvation after 1 day of starvation in either of the light treatments, thus data were merged for each irradiance (One way-ANOVA, $P>0.05$ ). Data on respiration of prey starved cells are only available until day 16 and 17 for the high and low irradiances, respectively. Starved cells had approximately halved their respiration rates $[42.9 \pm 7.1$ $(n=11)$ and $36.2 \pm 6.6(n=12) \mathrm{pg} \mathrm{C}$ cell $^{-1} \mathrm{~h}^{-1}$ at $I_{100}$ and $I_{15}$, respectively]; respiration rates at the two irradiances were not statistically different (Two way-ANOVA, $P>0.05$ ).

\section{DISCUSSION}

The present study documents for the first time that kleptochloroplasts (without prey nuclear material) taken up by $D$. acuta exhibit photoregulation, where photosynthetic pigments are produced to improve growth under both high and low irradiances. However, we saw no changes in photosynthesis vs. irradiance parameters like $\alpha$ rETR or max rETR during 1 month of starvation, similar to what is usually found in regular 


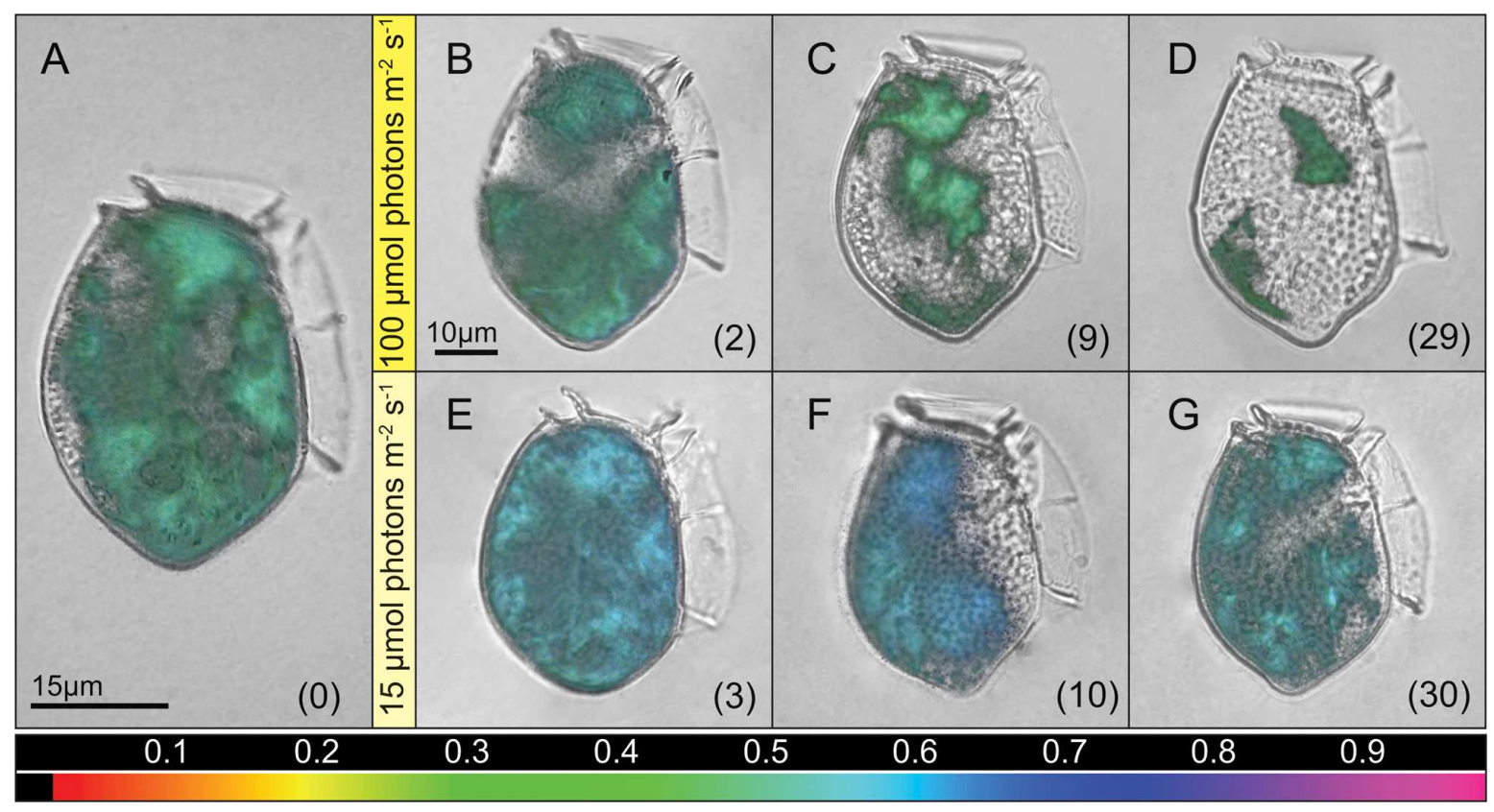

FIGURE 3 | Single cell variable chlorophyll fluorescence imaging. Maximum PSIl quantum yield $\left(F_{\mathrm{v}} / F_{\mathrm{m}}\right)$ of single $D$. acuta cells during the starvation experiment. Images display cells at different time points with the quantum yield as an overlay in false color (values corresponding to the color scalebar). A culture representative image for fed cells growing at $I_{100}$ prior to starvation (A), and culture representative images for starved cells after transfer to irradiances of $I_{100}(\mathbf{B}-\mathbf{D})$ and $I_{15}$ (E-G). Numbers in brackets presents days of starvation, and time maintained under the given irradiance.

algae displaying photoacclimation (e.g., MacIntyre et al., 2001). Thus, we found photoregulation but not true photoacclimation in D. acuta.

Under low irradiance, photoregulation enabled D. acuta to maintain their cellular Chl $a$ and phycoerythrin contents even though cells divided several times. We also found that the concentration of the alloxanthin increased relative to Chl $a$ in cells exposed to high irradiance, while this pigment was initially reduced in cells incubated under low irradiance. While the role of alloxanthin as a light harvesting or photoprotective pigment in cryptophytes is not well established, the few available reports suggest that the alloxanthin:Chl $a$ ratio in cryptophytes is elevated at high irradiances indicating that it may have photoprotective properties (Schlüter et al., 2000; Laviale and Neveux, 2011) and alloxanthin may thus play a similar role in D. acuta.

The literature provides no evidence for division of kleptochloroplasts in Dinophysis spp., suggesting that the cellular number of chloroplasts will decrease during cell division (Minnhagen et al., 2008). Hence, the ability of Dinophysis to maintain cellular photosynthetic pigment concentrations may potentially lead to enlargement (rather than division) of individual chloroplasts (Nielsen et al., 2013). Enlargement of kleptochloroplasts has recently been shown in other dinoflagellates such as Nusuttodinium aeruginosum and N. myriopyrenoides, where a 20-fold enlargement of the chloroplasts was observed within 120 min after ingestion in N. aeruginosum (Yamaguchi et al., 2011; Onuma and Horiguchi, 2015). Up to 10-fold enlargement of ingested chloroplasts has also been observed in the katablepharid Hatena arenicola
(Yamaguchi et al., 2011). However, in all these cases, prey nuclei and nucleomorphs were retained by the host cell, which is not the case in Dinophysis spp.

Variable chlorophyll fluorescence data suggested that chloroplasts in $D$. acuta were competent with maximum PSII quantum yields $\left(F_{\mathrm{v}} / F_{\mathrm{m}}\right)$ between 0.5 and 0.8 throughout the duration of the experiment ( 30 days). These values are similar to what is usually found in well-functioning microalgae (Falkowski and Raven, 2007). Similar observations have been obtained on D. caudata cells starved for up to 85 days (Park et al., 2008), where $F_{\mathrm{v}} / F_{\mathrm{m}}$ began to decline after 24 days of starvation, and reached 0.4 after 45 days of starvation, i.e., at the same time as cell divisions stopped. Thereafter, $F_{\mathrm{V}} / F_{\mathrm{m}}$ decreased steadily over the next days and reached zero after 85 days of starvation. We saw no indications of photodamage. Photodamage would be characterized by a decrease in $\phi_{\mathrm{NPQ}}$, which is one of the most important safety valves for the regulation of light harvest (Müller et al., 2001). Also, if the cells were photodamaged we would have expected to see a consecutive decrease of qP (Mackey et al., 2008), which gives information if photosynthetic efficiency has been altered by a changed proportion of functional reaction centers. In our case, $\phi_{\mathrm{NPQ}}$ was relatively stable $(\sim 20 \%)$ and $\mathrm{qP}$ was constant in high light (60-70\%) throughout the experiment, so the cells were unlikely to experience photodamage.

The prey species of Dinophysis spp., i.e., the red Mesodinium spp. retain ingested cryptophyte nuclei for up to 100 days and these have been shown to be transcriptionally active (Johnson et al., 2007; Lasek-Nesselquist et al., 2015). However, it has also been shown that the expression of a cryptophyte nuclear-encoded 
A

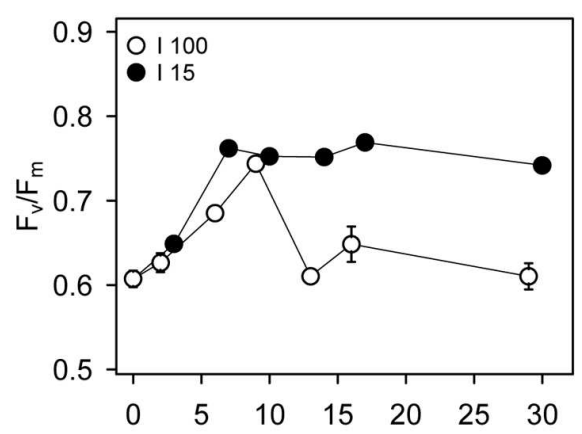

B

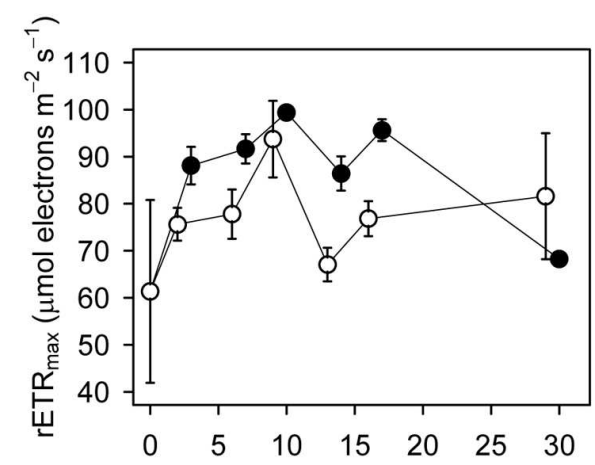

C

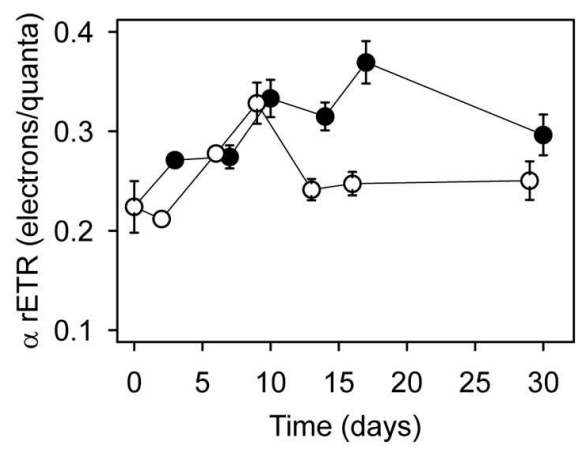

FIGURE 4 | Variable chlorophyll fluorescence measurements on $D$. acuta culture samples incubated at $I_{100}(0)$ and $I_{15}(\bullet)$ as a function of time after initiation of prey starvation. The culture had been growing at $I_{100}$ prior to the initiation of the experiment. (A) Maximum PSII quantum yield $\left(F_{\mathrm{v}} / F_{\mathrm{m}}\right)$. (B) Maximum relative electron transport rates (rETRmax) and (C) initial slopes of the light response curves ( $\alpha$ rETR), i.e., rETR vs irradiance. Data points represent the mean value parameter estimates obtained from the rapid light response curves. Error bars show standard error of the mean $(n=3)$.

gene for the plastid-targeted protein, LHCC10, involved in plastid function, declined in Mesodinium cells as the sequestered nuclei disappeared from the population (Johnson et al., 2007). In the red Mesodinium spp., $F_{\mathrm{v}} / F_{\mathrm{m}}$ values of $0.54-0.66$ have been observed when grown for up to a month without prey (Johnson et al., 2006; Kim et al., 2014).

Another kleptochloroplastidic dinoflagellate, Amylax triacantha, also preys on red Mesodinium spp. like Dinophysis spp. (Kim et al., 2014). Besides the cryptophyte chloroplasts,
A

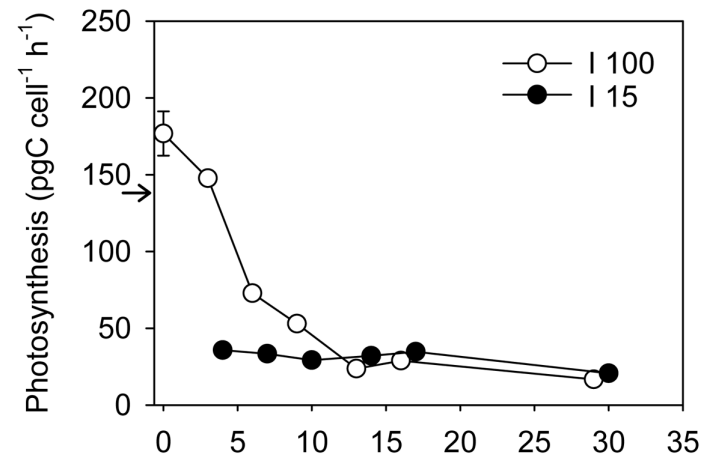

B

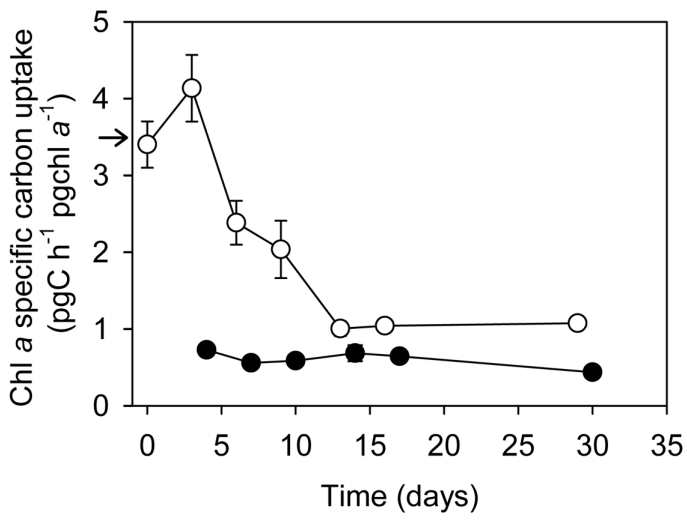

FIGURE 5 | Changes in (A) Cellular inorganic carbon uptake (pg C cell $^{-1} \mathrm{~h}^{-1}$ ), and (B) Chl a-specific inorganic carbon uptake (pg C pg $\mathrm{Chl} \mathrm{a}^{-1} \mathrm{~h}^{-1}$ ) in $D$. acuta during the prey starvation experiment at two irradiances, $\boldsymbol{I}_{\mathbf{1 0 0}}(\mathbf{0})$ and $\boldsymbol{I}_{\mathbf{1 5}}(\bullet)$, respectively. Data points represent treatment means and error bars indicate standard errors $(n=3)$. Arrows indicate values from well fed cultures for comparison.

A. triacantha also retains cryptophyte mitochondria, cryptophyte nuclei and nucleomorphs. However, unlike in M. rubrum, the ingested cryptophytes are kept as individual packages. In $A$. triacantha cultures subjected to prey starvation, $F_{\mathrm{v}} / F_{\mathrm{m}}$ remains at 0.6 for the first 5-8 days, whereafter it declines over time to reach $F_{\mathrm{V}} / F_{\mathrm{m}}$ values of $\sim 0.05$ after 25 days of prey starvation in conjunction with the loss of cryptophyte nuclear material, i.e., a much faster decline in photosynthetic capacity compared to the red Mesodinium spp.

Available evidence thus suggests that the cryptophyte chloroplasts are not independent entities, which will function on their own inside a host cell. In the red Mesodinium spp. and in A. triacantha the photosynthetic performance of kleptochloroplasts is coupled to the sequestration of prey nuclei and nucleomorph material. This is not the case in Dinophysis spp. Thus, it seems that the function of chloroplasts in Dinophysis may depend upon genes, which in the past have been transferred from prey nuclei and nucleomorphs to the dinoflagellate genome.

Very little is known about the transfer of genes from the cryptophyte genome to the genome of Dinophysis spp., and only one species, D. acuminata, has been investigated (Wisecaver and 
Hackett, 2010). Five proteins, complete with plastid-targeting peptides that may function in photosystem stabilization and metabolite transport, have been found encoded in the nuclear genome of D. acuminata (Wisecaver and Hackett, 2010). It seems unlikely that those genes alone allow for the extensive regulation of photosynthetic and photoprotective pigments that we observed in D. acuta, and more genes controlling photoregulation in D. acuta and other Dinophysis spp. remain to be identified.

The Chl a-specific inorganic carbon uptake dropped dramatically in cells grown at high irradiance indicating that, although $D$. acuta was able to produce Chl $a$, this did not translate into increased inorganic carbon uptake. There may be several reasons for this observation: First, since Dinophysis spp. only sequester the chloroplasts from their prey, any loss of genes involved in the regulation of RuBisCO that are located in the cryptophyte nuclei material are lost and this will strongly affect inorganic carbon fixation. Such genes may come from the prey nucleus, but they may also come from the nucleomorph. The Rubisco regulatory protein, CbbX, for instance, is encoded by the cryptophyte nucleomorph in cryptophytes (Maier et al., 2000).

Second, RuBisCo is located in the single terminally placed pyrenoid, contained by every chloroplast in most algae (Holdsworth, 1971; Giordano et al., 2005; Garcia-Cuetos et al., 2010). As D. acuta cannot divide the aquired chloroplasts, it will also be unable to divide its pyrenoids, which seems to be a key missing control factor, lacked by these protists to fully regulate and divide the sequestered "third hand" chloroplasts.

In purely phototrophic dinoflagellates, respiration rates typically account for $\sim 20$ and $\sim 40 \%$ of gross photosynthesis in the exponential and stationary growth phase, respectively (Geider and Osborne, 1989; Geider, 1992; López-Sandoval et al., 2014). In the kleptochloroplastidic D. acuta, respiration rates accounted for $\sim 50 \%$ of gross photosynthesis in well fed cells, and that percentage increased when the cells were subjected to prey starvation. Under high irradiance, D. acuta cells became full of storage material (unpublished observations, probably lipids and starch; Durand-Clement et al., 1988) upon initiation of prey starvation, in accordance with earlier observations in D. caudata (Park et al., 2008). Accordingly, we found excess inorganic carbon uptake during the first $\sim 9$ days under high irradiance, whereafter respiration rates started to slightly exceed rates of inorganic carbon uptake. Under low irradiance, respiration rates slightly exceeded the inorganic carbon uptake at all times. The build up of carbon storage upon onset of prey starvation and maintenance of fully active kleptochloroplasts thus allows D. acuta to survive for extended periods of time (months; Park et al., 2008; Nielsen et al., 2012, 2013). This is an important trait of these kleptochloroplastidic dinoflagellates, and explains how they can survive in a fluctuating environment and still depend upon $M$. rubrum as a single type of prey.

\section{CONCLUSION}

We found strong evidence of photoregulation via production of photosynthetic and photoprotective pigments in the klepto- chloroplastidic dinoflagellate, $D$. acuta, which only retains the chloroplasts from its prey. No direct evidence of changes in photosynthetis vs. irradiance parameters and thus no signs of photoacclimation were observed in D. acuta incubated at different irradiances, and thus no signs of photoacclimation were found. A decrease in Chl a-specific inorganic carbon uptake in prey-starved cells indicated a dilution of carbon fixing units (Rubisco) among daughter cells in combination with the production of $\mathrm{Chl} a$. However, in their natural environment $D$. acuta and the $>100$ species that belong to the genus Dinophysis may also indirectly photoregulate via increased retention of kleptochloroplasts, when prey cells are available. It is also possible that Dinophysis cells may indirectly achieve "photoacclimation" by ingestion of photoacclimated prey cells and maintaining a higher number of chloroplasts. Our data point to a hitherto unstudied role of gene transfer from prey to $D$. acuta that may enable it to regulate the function of its kleptochloroplast, although the exact genetic and biochemical mechanisms remain to be identified.

\section{AUTHOR CONTRIBUTIONS}

All authors were involved in the design and planning of the experiments. $\mathrm{PH}$ prepared the cultures for experimentation and was in charge of sampling scheme, carried out all ${ }^{14} \mathrm{C}$ measurements and data analysis, except for the last sampling where TB carried out the measurements. TB did all respiration measurements and data analysis, isolation of cells for all pigment analyses and carried out fluorometric measurements and connected data analysis of phytopigments. ET carried out all Imaging PAM and HPLC measurements of phytopigments and the connected data analysis. KO carried out all MultiColorPAM measurements and the connected data analysis. $\mathrm{PH}$ wrote the manuscript with inputs from all of the co-authors.

\section{FUNDING}

This work was supported by the Villum Foundation via the "Centre for Ocean Life" (PH, TB, and LN), a grant from the Danish Research Council for Independent Research, grant no 4181-00484 (PH), VKR Institutional funding IUT (19-6) for the Estonian Ministry of Education and Research and by the Estonian Science Foundation, grant no 8930 (KO), an EliteForsk Travel Award from the Danish Ministry of Higher Education and Science, no 1323-00065B (ET), and a Sapere Aude Advanced Grant from the Danish Research Council for Independent Research of Natural Science (MK), grant no 3071-00007B.

\section{SUPPLEMENTARY MATERIAL}

The Supplementary Material for this article can be found online at: http://journal.frontiersin.org/article/10.3389/fmicb.2016. 00785 


\section{REFERENCES}

Durand-Clement, M., Clement, J.-C., Moreau, A., Jeanne, N., and Puiseux-Dao, S. (1988). New ecological and ultrastructural data on the dinoflagellate Dinophysis sp. from the French coast. Mar. Biol. 97, 37-44. doi: 10.1007/BF00391243

Falkowski, P. G., and Raven, J. A. (2007). "The photosynthetic light reactions," in Aquatic Photosynthesis, 2nd Edn, eds P. G. Falkowski and J. A. Raven (Oxfordshire: Princeton University Press), 81-117.

Frigaard, N. U., Larsen, K. L., and Cox, R. P. (1996). Spectrochromatography of photosynthetic pigments as a fingerprinting technique for microbial phototrophs. FEMS Microb. Ecol. 20, 69-77. doi: 10.1111/j.15746941.1996.tb00306.x

Garcia-Cuetos, L., Moestrup, Ø, Hansen, P. J., and Daugbjerg, N. (2010). The toxic dinoflagellate Dinophysis acuminata harbors permanent chloroplasts of cryptomonad origin, not kleptochloroplasts. Harmful Algae 9, 25-38. doi: 10.1016/j.hal.2009.07.002

Geider, R. J. (1992). "Respiration: taxation without representation?, in Primary Productivity and Biogeochemical Cycles in the Sea, eds P. G. Falkowski and A. D. Woodhead (London: Plenum Press), 333-360.

Geider, R. J., and Osborne, B. A. (1989). Respiration and microalgal growth: a review of the quantitative relationship between dark respiration and growth. New Phytol. 112, 327-341. doi: 10.1111/j.1469-8137.1989.tb00321.x

Giordano, M., Beardall, J., and Raven, J. A. (2005). CO2 concentrating mechanisms in algae: mechanisms, environmental modulation, and evolution. Annu. Rev. Plant Biol. 56, 99-131. doi: 10.1146/annurev.arplant.56.032604.144052

Guillard, R. R. L. (1983). "Culture of the phytoplankton for feeding invertebrate animals," in Culture of Marine Invertebrates, ed. C. J. Berg (Stroudsberg, PA: Hutchinson Ross), 123-128.

Hansen, P. J. (2002). The effect of high $\mathrm{pH}$ on the growth and survival of marine phytoplankton: implications for species succession. Aquat. Microb. Ecol. 28, 279-288. doi: 10.3354/ame028279

Hansen, P. J., and Fenchel, T. (2006). Mesodinium rubrum harbours a permanent endosymbiont. Mar. Biol. Res. 2, 169-177. doi: 10.1080/17451000600719577

Hansen, P. J., Moldrup, M., Tarangkoon, W., Garcia-Cuetos, L., and Moestrup, $\emptyset$. (2012). Direct evidence for symbiont sequestration in the marine red tide ciliate Mesodinium rubrum. Aquat. Microb. Ecol. 66, 63-75. doi: 10.3354/ ame01559

Hansen, P. J., Nielsen, L. T., Johnson, M. D., Berge, T., and Flynn, K. J. (2013). Acquired phototrophy in Mesodinium and Dinophysis - a review of cellular organization, prey selectivity, nutrient uptake and bioenergetics. Harmful Algae 28, 126-139. doi: 10.1016/j.hal.2013.06.004

Holdsworth, R. H. (1971). The isolation and partial characterization of the pyrenoid protein of Eremosphaera viridis. J. Cell Biol. 51, 499-513. doi: 10.1083/jcb.51.2.499

Johnson, M. D. (2011). The acquisition of phototrophy: adaptive strategies of hosting endosymbionts and organelles. Photosynth. Res. 107, 117-132. doi: 10.1007/s11120-010-9546-8

Johnson, M. D., Oldach, D., Delwiche, C. F., and Stoecker, D. K. (2007). Retention of transcriptionally active cryptophyte nuclei by the ciliate Myrionecta rubra. Nature 445, 426-428. doi: 10.1038/nature05496

Johnson, M. D., and Stoecker, D. K. (2005). Role of feeding in growth and photophysiology of Myrionecta rubra. Aquat. Microb. Ecol. 39, 303-312. doi: 10.3354/ame039303

Johnson, M. D., Tengs, T., Oldach, D., and Stoecker, D. K. (2006). Sequestration, performance, and functional control of cryptophyte plastids in the ciliate Myrionecta rubra (Ciliophora). J. Phycol. 42, 1235-1246. doi: 10.1111/j.15298817.2006.00275.x

Kim, M., Kim, K. Y., Nam, S. W., Shin, W., Yih, W., and Park, M. G. (2014), The effect of starvation on plastid number and photosynthetic performance in the kleptoplastidic dinoflagellate Amylax triacantha. J. Eukaryot. Microb. 61, 354-363. doi: $10.1111 /$ jeu. 12115

Kim, M., Nam, S. W., Shin, W., Coats, D. W., and Park, M. G. (2012). Dinophysis caudata (Dinophyceae) sequesters and retains plastids from the mixotrophic ciliate prey Mesodinium rubrum. J. Phycol. 48, 569-579. doi: 10.1111/j.15298817.2012.01150.x

Lasek-Nesselquist, E., Wisecaver, J. H., Hackett, J. D., and Johnson, M. D. (2015). Insights into transcriptional changes that accompany organelle sequestration from the stolen nucleus of Mesodinium rubrum. BMC Genomics 16:805. doi: 10.1186/s12864-015-2052-9

Laviale, M., and Neveux, J. (2011). Relationships between pigment ratios and growth irradiance in 11 marine phytoplankton species. Mar. Ecol. Prog. Ser. 425, 63-77. doi: 10.3354/meps09013

López-Sandoval, D. C., Rodríguez-Ramos, T., Cermeño, P., Sobrino, C., and Marañón, E. (2014). Photosynthesis and respiration in marine phytoplankton: relationship with cell size, taxonomic affiliation, and growth phase. J. Exp. Mar. Biol. Ecol. 457, 151-159. doi: 10.1016/j.jembe.2014.04.013

MacIntyre, H. L., Kana, T. M., Anning, T., and Geider, R. J. (2001). Photoacclimation of photosynthesis irradiance response curves and photosynthetic pigments in microalgae and cyanobacteria. J. Phycol. 38, 17-38. doi: 10.1046/j.1529-8817.2002.00094.x

Mackey, K. R. M., Paytan, A., Grossman, A. R., and Bailey, S. (2008). A photosynthetic strategy for coping in a high-light, low-nutrient environment. Limnol. Oceanogr. 53, 900-913. doi: 10.4319/lo.2008.53.3.0900

Maier, U. G., Fraunholz, M., Zauner, S., Penny, S., and Douglas, S. (2000). A nucleomorph-encoded CbbX and the phylogeny of RuBisCo regulators. Mol. Biol. Evol. 17, 576-583. doi: 10.1093/oxfordjournals.molbev.a026337

Minnhagen, S., Carvalho, W. F., Salomon, P. S., and Janson, S. (2008). Chloroplast DNA content in Dinophysis (Dinophyceae) from different cell cycle stages is consistent with kleptoplasty. Environ. Microbiol. 10, 2411-2417. doi: 10.1111/j.1462-2920.2008.01666.x

Moeller, H. V., Johnson, M. D., and Falkowski, P. G. (2011). Photoacclimation in the phototrophic marine ciliate Mesodinium rubrum (Ciliophora). J. Phycol. 47, 324-332. doi: 10.1111/j.1529-8817.2010.00954.x

Müller, P., Li, X.-P., and Niyogi, K. N. (2001). Non-photochemical quenching. A response to excess light energy. Plant Physiol. 125, 1558-1566. doi: 10.1104/pp.125.4.1558

Nielsen, L. T., Krock, B., and Hansen, P. J. (2012). Influence of irradiance and food availability on DSP toxin production, growth and photosynthesis in Dinophysis acuminata. Mar. Ecol. Prog. Ser. 471, 34-50. doi: 10.3354/ meps 10027

Nielsen, L. T., Krock, B., and Hansen, P. J. (2013). Production and excretion of okadaic acid, pectenotoxin-2 and a novel dinophysistoxin from the DSP-causing marine dinoflagellate Dinophysis acuta - effects of light, food availability and growth phase. Harmful Algae 23, 34-45. doi: 10.1016/j.hal.2012.12.004

Nielsen, L. T., Lundholm, N., and Hansen, P. J. (2007). Does irradiance influence the tolerance of marine phytoplankton to high pH? Mar. Biol. Res. 3, 446-453. doi: 10.1080/17451000701711820

Onuma, R., and Horiguchi, T. (2015). Kleptochloroplast enlargement, karyoklepty and the distribution of the cryptomonad nucleus in Nusuttodinium ( = Gymnodinium) aeruginosum. Protist 166, 177-195. doi: 10.1016/j.protis.2015.01.004

Park, M. G., Kim, S., Kim, H. S., Myung, G., and Kang, Y. G. (2006). First successful culture of the marine dinoflagellate Dinophysis acuminata. Aquat. Microb. Ecol. 45, 101-106. doi: 10.3354/ame045101

Park, M. G., Park, J. S., and Kim, M. (2008). Plastid dynamics during survival of Dinophysis caudata without its ciliate prey. J. Phycol. 44, 1154-1163. doi: 10.1111/j.1529-8817.2008.00579.x

Poulsen, L. K., Moldrup, M., Berge, T., and Hansen, P. J. (2011). Feeding on fecal pellets - a new trophic role for dinoflagellates as detritivores. Mar. Ecol. Prog. Ser. 441, 65-77. doi: 10.3354/meps09357

Rial, P., Garrido, J. L., Jaén, D., and Rodríguez, F. (2013). Pigment composition in three Dinophysis species (Dinophyceae) and the associated cultures of Mesodinium rubrum and Teleaulax amphioxeia. J. Plankton Res. 35, 433-437. doi: $10.1093 /$ plankt/fbs099

Schlüter, L., Møhlenberg, F., Havskum, H., and Larsen, S. (2000). The use of phytoplankton pigments for identifying and quantifying phytoplankton groups in coastal areas: testing the influence of light and nutrients on pigment/chlorophyll a ratios. Mar. Ecol. Prog. Ser. 192, 49-63. doi: 10.3354/meps192049

Schreiber, U., Bilger, W., and Neubauer, C. (1994). "Chlorophyll fluorescence as a non-intrusive indicator for rapid assessment of in vivo photosynthesis," in Ecological Studies, Vol. 100, eds E.-D. Schulze and M. M. Caldwell (Heidelberg: Springer), $49-70$. 
Skovgaard, A., Hansen, P. J., and Stoecker, D. K. (2000). Physiology of the mixotrophic dinoflagellate Fragilidium subglobosum. I. Effects of phagotrophy and irradiance on photosynthesis and carbon content. Mar. Ecol. Prog. Ser. 201, 129-136. doi: 10.3354/meps201129

Smith, M., and Hansen, P. J. (2007). Interaction between Mesodinium rubrum and its prey: importance of prey concentration, irradiance and pH. Mar. Ecol. Prog. Ser. 338, 61-70. doi: 10.3354/meps338061

Stoecker, D. K., Johnson, M. D., de Vargas, C., and Not, F. (2009). Acquired phototrophy in aquatic protists. Aquat. Microb. Ecol. 57, 279-310. doi: 10.3354/ame 01340

Trampe, E., Hansen, P. J., and Kühl, M. (2015). A comparison of photosynthesis measurements by $\mathrm{O} 2$ evolution, $14 \mathrm{C}$ assimilation and variable chlorophyll fluorescence during light acclimatization of the diatom Coscinodiscus granii. Algae 30, 103-119. doi: 10.4490/algae.2015.30. 2.103

Trampe, E., Kolbowski, J., Schreiber, U., and Kühl, M. (2011). Rapid assessment of different oxygenic phototrophs and single cell photosynthesis with multicolour variable chlorophyll fluorescence imaging. Mar. Biol. 158, 1667-1675. doi: 10.1007/s00227-011-1663-1
Wisecaver, J. H., and Hackett, J. D. (2010). Transcriptome analysis reveals nuclearencoded proteins for the maintenance of temporary plastids in the dinoflagellate Dinophysis acuminata. BMC Genomics 11:360. doi: 10.1186/1471-2164-11-366

Yamaguchi, H., Nakayama, T., Kai, A., and Inouye, I. (2011). Taxonomy and phylogeny of a new kleptoplastidal dinoflagellate Gymnodinium myriopyrenoides sp. nov. (Gymnodiniales, Dinophyceae) and its cryptophyte symbiont. Protist 162, 650-677. doi: 10.1016/j.protis.2011.01.002

Conflict of Interest Statement: The authors declare that the research was conducted in the absence of any commercial or financial relationships that could be construed as a potential conflict of interest.

Copyright (C) 2016 Hansen, Ojamäe, Berge, Trampe, Nielsen, Lips and Kühl. This is an open-access article distributed under the terms of the Creative Commons Attribution License (CC BY). The use, distribution or reproduction in other forums is permitted, provided the original author(s) or licensor are credited and that the original publication in this journal is cited, in accordance with accepted academic practice. No use, distribution or reproduction is permitted which does not comply with these terms. 